\title{
ISOLASI DAN UJI ANTIBAKTERI DARI BAKTERI YANG BERASOSIASI DENGAN SPONS Phyllospongia lamellose SERTA IDENTIFIKASI SECARA BIOKIMIA
}

\author{
Sela S. Lempoy ${ }^{1)}$, Widya A. Lolo ${ }^{1)}$, Paulina V. Y. Yamlean ${ }^{1)}$ \\ ${ }^{1)}$ Program Studi Farmasi FMIPA UNSRAT Manado, 95115
}

\begin{abstract}
Sponges are one source of producing bioactive components from the sea. Bacteria Symbiosis with sponges are thought to have the potential to produce bioactive compounds that have been isolated from sponges. One of the potential of bioactive compounds which have been found and developed from sponges was antibacterial. The aim of this study was to determine the antibacterial activity of bacteria associated with Phyllospongia lamellose sponges against pathogenic bacteria namely Staphylococcus aureus and Esherichia coli and then proceed with identification of biochemistry in isolates which showed the greatest inhibitory activity. Three isolates of sponges symbiont bacteria were obtained through the isolation and purification stage which were then followed by testing of antibacterial activity with paper disk diffusion method. The antibacterial test results showed the diameter of the inhibitory zone against Staphylococcus aureus, were: $S L_{1}(8.67 \mathrm{~mm}), S L_{2}(9.33 \mathrm{~mm})$ and $S L_{3}(9.00 \mathrm{~mm})$ categorized as medium. Whereas the inhibiotion zone shown on Esherichia coli bacteria is also classified as medium, were: $S L_{1}(9.67 \mathrm{~mm}), S L_{2}(9.00 \mathrm{~mm})$ and $S L_{3}(9.33 \mathrm{~mm})$. The three isolates continued to the identification stage biochemically. Each isolation was assumed as follows: Desulfotomaculum $\left(S L_{1}\right)$, Brochothrix $\left(S L_{2}\right)$ and Sulfidobacillus $\left(S L_{3}\right)$.
\end{abstract}

Keyword : : : $\quad$ hyllospongia lamellose, isolation, biochemically identification

\begin{abstract}
ABSTRAK
Spons merupakan salah satu sumber penghasil komponen bioaktif yang berasal dari laut. Bakteri yang bersimbiosis dengan spons diduga memiliki potensi dalam menghasilkan senyawa-senyawa bioaktif yang telah diisolasi dari spons. Potensi senyawa bioaktif yang telah ditemukan dan dikembangkan dari spons salah satunya ialah sebagai antibakteri. Penelitian ini bertujuan untuk mengetahui aktivitas antibakteri dari bakteri yang berasosiasi dengan spons Phyllospongia lamellose terhadap bakteri patogen yakni Staphylococcus aureus dan Escherichia coli dan kemudian dilanjutkan dengan identifikasi secara biokimia pada isolat yang menunjukkan daya hambat terbesar. Diperoleh 3 isolat bakteri simbion spons melalui tahap isolasi dan purifikasi yang kemudian dilanjutkan dengan pengujian aktivitas antibakteri melalui metode difusi kertas cakram. Hasil uji antibakteri menunjukkan diameter zona hambat terhadap bakteri Staphylococcus aureus yaitu: $\mathrm{SL}_{1}(8.67 \mathrm{~mm})$, $\mathrm{SL}_{2}(9.33 \mathrm{~mm})$ dan $\mathrm{SL}_{3}(9.00 \mathrm{~mm})$ termasuk dalam kategori sedang. Sedangkan zona hambat yang ditunjukkan terhadap bakteri Escherichia coli juga tergolong kategori sedang yaitu: $\mathrm{SL}_{1}(9.67 \mathrm{~mm}), \mathrm{SL}_{2}(9.00 \mathrm{~mm})$ dan $\mathrm{SL}_{3}$ $(9.33 \mathrm{~mm})$. Ketiga isolat dilanjutkan ke tahap identifikasi secara biokimia. Masing-masing isolat diduga sebagai berikut: Desulfotomaculum $\left(\mathrm{SL}_{1}\right)$, Brochothrix $\left(\mathrm{SL}_{2}\right)$ dan Sulfidobacillus $\left(\mathrm{SL}_{3}\right)$.
\end{abstract}

Kata kunci $\quad$ :Phyllospongia lamellose, isolasi, identifikasi biokimia. 


\section{PENDAHULUAN}

Pemanfaatan organisme laut tidak hanya terbatas sebagai bahan makanan dan bahan kosmetik, namun berpotensi juga sebagai bahan obat alam (Achiruddin, 2005). Bakteri yang berasosiasi dengan spons dapat menghasilkan senyawa komponen bioaktif. Bioaktivasi senyawa hasil isolasi bakteri simbion spons meliputi antitumor, antivirus, antimikroba atau sifat umum sitotoksik (Oki et al., 2014).

Identifikasi dapat dilakukan secara konvensional melalui karakterisasi biokimia dan mikroskopis sel bakteri, hingga berbasis molekuler. Penentuan genus isolat bakteri dapat ditentukan sesuai dengan literatur Bergey's Manual of Determinative Bacteriology yang disertai pengamatan mikroskopis melalui beberapa uji yakni uji biokimia dan uji morfologi.

\section{METODE}

\section{Alat}

Alat yang digunakan dalam penelitian ini yaitu masker, sarung tangan, gunting, scuba diving, zipper bag, kamera bawah laut, wadah, cooling box, pisau, erlenmeyer (Iwaki ST Pyrex), timbangan digital (ADAM), gelas ukur (Iwaki ST Pyrex), gelas kimia, cawan petri (Iwaki ST Pyrex), autoklaf (ALP), pinset, spatula, bunsen, pipet tetes, L-glass, batang pengaduk, laminar air flow (Biotek), rak tabung reaksi, rotary shaker incubator (Infors HT), lumpang dan alu, tabung reaksi, lemari pendingin, plastik wrap, kertas label, aluminium foil, tisu, kasa, mikroskop cahaya, kaca objek, alat fotografi, kertas cakram kosong(paper disc), mikropipet (Ecopipette), jangka sorong, jarum ose, jas lab, kertas cakram antibiotik tetrasiklin.

\section{Bahan}

Bahan-bahan yang digunakan yaitu spons, bakteri uji Escherichia Coli dan Staphylococcus Aureus, media Nutrient Agar, media Nutrient Broth, aquades, $\mathrm{NaCl} 0.9 \%$, kristal violet, safranin, etanol 70\%, lugol, Triple Sugar Iron (TSI), minyak imersi, Simmon's Citrate Agar, reagen covac's, hidrogen peroksida, Lysin Iron Agar.

\section{Prosedur Kerja}

\section{Pengambilan sampel}

Sampel spons diambil dari perairan teluk Manado menggunakan alat bantu menyelam. Sampel difoto dengan kamera bawah laut dan diambil lalu dimasukkan ke dalam ziper bag dan disimpan dalam cooling box berisi es batu untuk dibawa ke Laboratorium Mikrobiologi Farmasi Program Studi Fakultas Matematikan dan Ilmu Pengetahuan Alam Farmasi Universitas Sam Ratulangi. Sampel yang didiambil dicuci bersih dengan air mengalir kemudian dilakukan identifikasi secara morfologi di Laboratorium Taksonomi Jurusan Biologi Fakultas Matematika dan Ilmu Pengetahuan Alam.

\section{Sterilisasi Alat}

Alat-alat gelas dan media yang digunakan disterilkan menggunakan autoklaf pada suhu $121^{\circ} \mathrm{C}$ selama 15 menit (Ortez, 2005). Sedangkan jarum ose, pinset dan L-glass dipijarkan diatas api secara langsung.

\section{Pembuatan media}

\section{Media Nutrient Agar (NA)}

\section{a. Media Pertumbuhan}

Media padat dibuat dengan menimbang sebanyak 5.04 g NA kemudian dimasukkan kedalam erlenmeyer dan dicukupkan dengan $180 \mathrm{~mL}$ aquades (28 g/ $1000 \mathrm{~mL}$ ) lalu dikocok hingga homogen. Setelah homogen media 
kemudian disterilkan dalam autoklaf pada suhu $121^{\circ} \mathrm{C}$ selama 15 menit, lalu didiamkan beberapa saat. Selanjutnya media dituang kedalam 12 cawan petri steril masing-masing $20 \mathrm{~mL}$. Media yang telah padat pada cawan petri diseal menggunakan plastik wrap sehingga tidak terkontaminasi. Media ini digunakan untuk penanaman awal bakteri simbion dari sampel yang telah diencerkan secara berseri, isoalsi bakteri dan untuk pengujian aktivitas antibakteri.

\section{b. Media Pembenihan}

Pada media pembenihan NA ditimbang sebanyak $2.52 \mathrm{~g}$ kemudian dimasukkan kedalam erlenmeyer dan dicukupkan dengan 90 $\mathrm{mL}$ aquades (28 g/ $1000 \mathrm{~mL})$ lalu dikocok hingga homogen. Setelah homogen media kemudian disterilkan dalam autoklaf pada suhu $121^{\circ} \mathrm{C}$ selama 15 menit, lalu didiamkan beberapa saat. Selanjutnya media dituang kedalam tabung reaksi steril masing-masing 10 $\mathrm{mL}$ (sebagai agar miring) dan didiamkan hingga media menjadi padat. Media pembenihan ini digunakan untuk inokulasi mikroba.

\section{Media Nutrient Broth (NB)}

Media cair dibuat dengan menimbang NB sebanyak 0.72 g kemudian dimasukkan dalam gelas kimia dan dicukupkan dengan $90 \mathrm{~mL}$ aquades (8 g/ $1000 \mathrm{~mL}$ ) lalu diaduk hingga homogen. Setelah homogen media cair kemudian disterilkan dalam autoklaf pada suhu $121^{\circ} \mathrm{C}$ selama 15 menit, lalu didiamkan beberapa saat. Selanjutnya media dituang kedalam erlenmeyer steril masing-masing 10 mL. Media ini akan digunakan untuk menginokulasikan bakteri simbion spons pada pengujian aktivitas antibakteri.

\section{Isolasi dan Purifikasi Bakteri Simbion}

Sampel spons ditimbang $1 \mathrm{~g}$ lalu digerus menggunakan alu dan lumpang sampai halus.
Selanjutnya akan dilakukan pengenceran sampel sebesar $10^{0}$ dengan memasukkan $1 \mathrm{~g}$ spons kedalam tabung reaksi yang sudah steril kemudian ditambahkan $\mathrm{NaCl}$ sebanyak $9 \mathrm{~mL}$. Setelah itu dilakukan pengenceran bertingkat untuk seri $10^{-1}$ dan $10^{-3}$. Diambil $100 \mu \mathrm{L}$ dari masing-masing seri lalu disebarkan kedalam cawan petri yang berisi media NA dan di inkubasi menggunakan inkubator pada suhu 27 $29^{\circ} \mathrm{C}$ selama $1 \times 24$ jam. Pengamatan dilakukan terhadap koloni bakteri yang telah tumbuh secara makroskopik yaitu mengamati bentuk, warna dan ukuran koloni bakteri. Kemudian koloni-koloni yang terpilih dipisahkan kedalam media cawan petri steril berisi media NA dan di inkubasi selama 1x24 jam dengan inkubator pada suhu $27-29^{\circ} \mathrm{C}$. Isolat bakteri murni yang diperoleh kemudian dipindahkan pada media miring NA sebagai stok.

\section{Pembuatan Larutan Mc. Farland 0.5}

Larutan $\mathrm{H}_{2} \mathrm{SO}_{4} \quad 1 \%$ sebanyak $9.5 \mathrm{~mL}$ dicampurkan dengan larutan $\mathrm{BaCl}_{2} \quad 1.75 \%$ sebanyak $0.5 \mathrm{~mL}$ dalam erlenmeyer. Kemudian dikocok sampai terbentuk larutan yang keruh. Kekeruhan ini dipakai sebagai standar kekeruhan suspensi bakteri uji (Borges et al., 2004).

\section{Pembuatan Suspensi Bakteri Uji}

Bakteri uji Escherichia coli dan Staphylococcus aureus diambil dengan jarum ose steril kemudian disuspensikan ke dalam tabung reaksi yang berisi $7 \mathrm{ml}$ larutan $\mathrm{NaCl}$ $0.9 \%$, hingga diperoleh kekeruhan yang sama dengan standar kekeruhan larutan Mc. Farland 0.5 .

\section{Pengujian Aktivitas Antibakteri}

Penyiapan bakteri simbion dengan cara menginokulasikan 1 ose bakteri simbion kedalam $10 \mathrm{~mL}$ media NB lalu diinkubasi selama 1x24 jam dengan rotary shaker incubator pada suhu $27-29^{\circ} \mathrm{C}$. Koloni bakteri 
simbion dalam media cair NB masing-masing dipindahkan ke dalam tabung sentrifuge lalu disentrifugasi dengan kecepatan 3000 rpm selama 30 menit. Hasil dari sentrifugasi akan membentuk supernatan yang kemudian akan diambil. Pada permukaan media disebarkan masing-masing bakteri uji sebanyak $100 \mu \mathrm{L}$, kemudian kertas cakram yang telah direndam dengan isolat bakteri simbion spons diletakkan pada permukaan media bersama dengan kontrol positif yaitu tetrasiklin dan kontrol negatif yaitu aquades. Setelah itu diinkubasi pada suhu $37^{\circ} \mathrm{C}$ selama 1x24 jam.

\section{Identifikasi Bakteri Simbion Melalui Uji Biokimia}

\section{Uji Katalase}

Media NB ditimbang sebanyak $0.12 \mathrm{~g}$ dan dilarutkan dalam $15 \mathrm{~mL}$ aquades. Setelah itu media dihomogenkan lalu disterilkan dalam autoklaf pada suhu $121^{\circ} \mathrm{C}$ selama 15 menit. Media kemudian dituang ke dalam tabung reaksi steril masing-masing sebanyak $5 \mathrm{~mL}$. Kemudian isolat bakteri diinokulasi menggunakan jarum ose ke dalam tabung reaksi yang berisi Nutrient Broth. Inkubasikan selama 24 jam pada suhu $37^{\circ} \mathrm{C}$. Setelah itu tambahkan 3-4 tetes 3\% hidrogen peroksida ke dalam media biakan. Diamati bila terjadi pembentukan gelembung maka uji ini bersifat positif.

\section{Uji Sitrat}

Media dibuat dengan menimbang Simmon's citrate sebanyak $0.36 \mathrm{~g}$ dan dicukupkan dalam $15 \mathrm{~mL}$ aquades. Isolat bakteri diinokulasikan ke dalam media SCA dengan cara digores lalu diinkubasi pada suhu $37^{\circ} \mathrm{C}$ selama 24 jam. Hasil positif apabila terjadi perubahan warna media dari hijau menjadi biru dan uji bersifat negatif apabila tidak terjadi perubahan warna pada media.

\section{Uji Lisin Dekarboksilase}

Lysin Iron Agar ditimbang sebanyak $0.52 \mathrm{~g}$ dan dilarutkan dalam $15 \mathrm{~mL}$ aquades. Isolat bakteri diinokulasi dengan cara tusukan, lalu diinkubasi pada suhu $37^{\circ} \mathrm{C}$ selama 24 jam. Perubahan warna dari ungu menjadi kuning dan kembali menjadi ungu menandakan bahwa hasil terhadap uji ini positif. Sedangkan hasil negatif ditandai dengan perubahan warna dari ungu menjadi kuning.

\section{Uji Fermantasi Karbohidrat}

Media TSIA ditimbang sebanyak $1.82 \mathrm{~g}$ dan dicukupkan dalam $28 \mathrm{~mL}$ aquades. Setelah itu media dihomogenkan lalu disterilkan dalam autoklaf pada suhu $121^{\circ} \mathrm{C}$ selama 15 menit. Media kemudian dituang ke dalam tabung reaksi steril masing-masing sebanyak $7 \mathrm{~mL}$. Isolat bakteri diinokulasikan kedalam media. Sisakan satu buah tabung yang tidak diinokulasi untuk digunakan sebagai kontrol, setelah itu semua diinkubasi selama 24 jam pada suhu $37^{\circ} \mathrm{C}$.

\section{Uji Indol}

Media dibuat dengan menimbang NA sebanyak $0.59 \mathrm{~g}$ dan dicukupkan dalam $21 \mathrm{~mL}$ aquades. Media yang telah homogen disterilkan di dalam autoklaf pada suhu $121^{\circ} \mathrm{C}$ selama 15 menit. Media kemudian dituang ke dalam tabung reaksi steril masing-masing sebanyak 7 $\mathrm{mL}$. Isolat bakteri diinokulasikan ke media dengan cara ditusukkan menggunakan jarum ose sedalam $3 / 4$ bagian. Setalah itu diinkubasi pada suhu $37^{\circ} \mathrm{C}$ selama 24 jam. Kemudian reagen covac's ditambahkan sebanyak 0.2-0.3 $\mathrm{mL}$ lalu diamati. Hasil positif apabila media bewarna merah pada saat penambahan reagen.

\section{6. $\mathrm{Uji} \mathrm{H}_{2} \mathrm{~S}$}

Media TSIA ditimbang sebanyak $1.8 \mathrm{~g}$ dan dilarutkan dalam $28 \mathrm{ml}$ aquades. Media yang telah homogen disterilkan di dalam autoklaf pada suhu $121{ }^{\circ} \mathrm{C}$ selama 15 menit. Media kemudian dituang ke dalam tabung reaksi steril 
masing-masing sebanyak $7 \mathrm{~mL}$. Setelah itu isolat bakteri diinokulasikan dengan cara digores lalu ditusuk. Masukkan dalam inkubator lalu diinkubasi pada suhu $37^{\circ} \mathrm{C}$ selama 24 jam. Hasil positif bila terbentuk warna hitam pada media. Hasil negatif bila media berubah warna menjadi kuning.

\section{Uji Motilitas}

Media NA ditimbang sebanyak $0.59 \mathrm{~g}$ dan dicukupkan dengan $21 \mathrm{~mL}$ aquades lalu. Setelah itu media disterilkan dalam autoklaf pada suhu $121^{\circ} \mathrm{C}$ selama 15 menit, kemudian dibiarkan hingga sedikit mendingin. Media dituangkan kedalam masing-masing tabung reaksi steril sebanyak $7 \mathrm{~mL}$. Kemudian isolat bakteri dinokulasikan ke dalam media dengan cara menusukkan jarum ose sampai ke dasar media dan tiap-tiap isolat diberikan kode pada masing-masing tabung. Dinkubasi pada $37^{\circ}$ selama 24 jam. Hasil pengamatan dicatat, uji motilitas dinyatakan positif apabila pertumbuhan bakteri melebar dibekas tusukan jarum ose.

\section{Hasil dan Pembahasan}

\section{Determinasi Sampel}

Sampel spons Phyllospongia lamellose yang diambil dari perairan teluk Manado dilakukan determinasi di Program Studi Biologi Fakultas Matematika dan Ilmu Pengetahuan Alam Universitas Sam Ratulangi. Tujuan dilakukannya determinasi untuk mengetahui sampel yang diambil ialah tepat sehingga terhindar dari kesalahan penggunaan sampel dalam penelitian. Hasil dari identifikasi sampel menunjukkan bahwa jenis spons yang hendak diteliti adalah spons Phyllospongia lamellose

\section{Isolasi dan Purifikasi Bakteri Simbion}

Sampel spons yang digunakan dibersihkan terlebih dahulu menggunakan aquades untuk menghilangkan kotoran dan mikroorganisme epifit agar koloni yang tumbuh pada media isolasi merupakan koloni bakteri simbion spons (Hafsari dan Asterina, 2013). Kemudian sampel dipotong kecil-kecil lalu digerus hingga halus menggunakan alu dan lumpang. Pengenceran $\mathrm{NaCl}$ secara bertingkat dimaksudkan agar bakteri yang dihasilkan tidaklah pekat. Hasil dari isolasi spons menunjukkan adanya pertumbuhan koloni-koloni bakteri pada media agar, kemudian dipilih 3 koloni bakteri yang berbeda berdasarkan pengamatan secara makroskopis dan diberi kode $\mathrm{SL}_{1}, \mathrm{SL}_{2}$ dan $\mathrm{SL}_{3}$. Lalu isolat-isolat tersebut dimurnikan lagi dengan menginokulasikannya ke media agar yang baru dan diinkubasi selama 1x24 jam.

\section{Pengujian Aktivitas Antibakteri}

Bakteri yang akan diuji disentrifugasi dengan tujuan untuk memperoleh bakteri yang aktif. Pengujian aktivitas antibakteri dilakukan dengan menggunakan metode difusi cakram kertas. Penggunan metode ini dikarenakan kemudahan dan kesederhanaannya saat dilakukan dan dengan metode difusi ini juga jumlah zat yang akan digunakan dapat diatur (Valgas et al., 2007).

Tabel 1. Hasil Pengukuran Diameter Zona Bening

\begin{tabular}{cccccc}
\hline \multirow{2}{*}{ Bakteri Uji } & \multicolumn{5}{c}{ Diameter Zona Bening $(\mathbf{m m})$} \\
\cline { 2 - 6 } & $\mathbf{K}+$ & $\mathbf{K}-$ & $\mathbf{S L}_{\mathbf{1}}$ & $\mathbf{S L}_{\mathbf{2}}$ & $\mathbf{S L}_{\mathbf{3}}$ \\
\hline Staphylococcus aureus & 13.67 & 0 & 8.67 & 9.33 & 9.00 \\
\hline Escherichia coli & 18.00 & 0 & 9.67 & 9.00 & 9.33 \\
\hline
\end{tabular}


Ket : K+ Kontrol positif; K- Kontrol negatif; $\mathrm{SL}_{1}$ Isolat; $\mathrm{SL}_{2}$ Isolat $\mathrm{SL}_{3}$ Isolat

Berdasarkan hasil penelitian yang dilakukan dan jika ditinjau dari karakterisasi kekuatan daya antibakteri, maka diameter rata-rata zona bening isolat bakteri yang berasosisasi dengan spons Phyllospongia lamellose terhadap bakteri Staphylococcus aures yaitu: $\mathrm{SL}_{1}(8.67 \mathrm{~mm})$, $\mathrm{SL}_{2}(9.33 \mathrm{~mm})$ dan $\mathrm{SL}_{3}(9.00 \mathrm{~mm})$ termasuk dalam kategori sedang. Pada diameter rata-rata zona bening yang dihasilkan oleh isolat bakteri yang bersimbion dengan spons Phyllospongia lamellose terhadap bakteri Escherichia coli juga termasuk dalam kategori daya antibakteri sedang yaitu: $\mathrm{SL}_{1}(9.67 \mathrm{~mm}), \mathrm{SL}_{2}(9.00 \mathrm{~mm})$ dan $\mathrm{SL}_{3}(9.33 \mathrm{~mm})$. Kemampuan aktivitas antibakteri menurut Brooks et al. (2008), dipengaruhi oleh konsentrasi ekstrak, kandungan senyawa antibakteri, daya difusi ekstrak dan juga salah satunya jenis bakteri yang dihambat. Staphylococcus aureus merupakan bakteri Gram positif yang memiliki struktur dinding sel dengan lebih banyak lapisan peptidoglikan dan membentuk struktur yang tebal dan kaku juga mengandung asam teikoat. Escherichia coli sebagai bakteri Gram negatif terdiri atas lapisan peptidoglikan yang relatif tipis, memiliki kandungan lipid yang banyak serta mempunyai porin yang berperan sebagai saluran masuknya zat aktif ke dalam sel bakteri, sehingga masuknya zat aktif ini dapat merusak aktivitas enzim dalam sel dan menyebabkan kerusakan sel serta dengan kadar lipid yang tinggi di dalam sel akan meningkatkan permeabilitas zat aktif ke dalam sel bakteri (Adila et al., 2013). Menurut Tansil et al (2016), perbedaan struktur dinding sel sangat menentukan penetrasi, ikatan dan juga aktivitas senyawa dari antibakteri.

\section{Identifikasi Secara Biokimia}

Pengujian dilanjutkan pada identifikasi isolat bakteri melalui uji morfologi dan uji biokimia.

\section{Tabel 2. Hasil Pengamatan Morfologi Isolat Bakteri Simbion}

\section{Kode Isolat}

$\mathrm{SL}_{1}$

$\mathrm{SL}_{2}$

$\mathrm{SL}_{3}$

\section{Bentuk Sel}

Basil

Basil

Basil

\section{Karakterisitik Bakteri}

\section{Gram}

Positif

Positif

Positif
Berdasarkan hasil pengamatan morfologi sel bakteri melalui metode pewarnaan Gram. Ketiga isolat bakteri simbion merupakan Gram positif dengan bentuk basil. Feliatra et al., (2004) mengatakan bahwa bakteri Gram positif merupakan bakteri yang memiliki dinding sel yang tebal dan membran sel selapis, sehingga pada saat bakteri mengalami dehidrasi dengan pemberian alkohol, pori-pori bakteri tersebut akan mengkerut yang menyebabkan warna utama (kristal violet) tidak bisa keluar. Interaksi antara sel bakteri dengan kristal violet akan semakin kuat dengan ditambahkannya lugol yang ketika dicuci dengan alkohol bakteri Gram positif akan tetap mengikat kompleks kristal violet-lugol sehingga menjadi warna ungu Prescot et al. dalam Hidayat (2011), akan tetapi bakteri Gram negatif akan kehilangan kompleks 
kristal violet-lugol karena lapisan peptidoglikan pada bakteri Gram negatif lebih tipis sehingga menjadi tidak berwarna. Ketika ditambahkan dengan safranin yang berwarna merah maka bakteri Gram negatif akan menyerapnya sedangkan bakteri Gram positif tidak akan menyerap pewarna lagi. Identifikasi bakteri dilakukan dengan teknik konvensional yaitu dengan membandingkan bakteri yang sedang diidentifikasi dengan bakteri yang telah teridentifikasi sebelumnya. Bila tidak terdapat bakteri dengan ciri-ciri $100 \%$ serupa, maka dilakukan pendekatan bakteri yang memiliki ciri-ciri yang paling menyerupai. Oleh karena itu teknik identifikasi dengan metode konvensional akan selalu menghasilkan suatu bakteri tertentu yang sudah teridentifikasi sebelumnya dan tidak akan dapat menemukan spesies baru (Harrow dan Feltham, 2003).

Tabel 3. Hasil Pengamatan Uji Biokimia Terhadap Isolat Bakteri Simbion

\begin{tabular}{cccccccc}
\hline $\begin{array}{c}\text { Kode } \\
\text { Isolat }\end{array}$ & Katalase & Sitrat & Lisin & $\begin{array}{c}\text { Fermentasi } \\
\text { Karbohidrat }\end{array}$ & Indol & $\mathbf{H}_{2} \mathbf{S}$ & Motilitas \\
\hline $\mathbf{S L}_{1}$ & - & - & + & - & - & + & - \\
$\mathbf{S L}_{2}$ & + & + & - & + & - & - & - \\
$\mathbf{S L}_{3}$ & + & - & + & - & - & + & - \\
\hline
\end{tabular}

Ket : + Hasil pengujian positif; - Hasil pengujian negative; $\mathrm{SL}_{1}$ Isolat; $\mathrm{SL}_{2}$ Isolat; $\mathrm{SL}_{3}$ Isolat

Uji biokimia pada isolat $\mathrm{SL}_{1}$ menunjukkan hasil negatif terhadap uji katalase dan uji fermentasi karbohidrat namun menunjukkan hasil positif terhadap uji $\mathrm{H}_{2} \mathrm{~S}$. Hasil yang diperoleh dilanjutkan dengan penentuan genus berdasarkan buku Bergey's Manual of Determinative Bacteriology $9^{\text {th }}$ Edition yang menyimpulkan bahwa bakteri tersebut diduga sebagai bakteri Desulfotomaculum. Hal ini sejalan dengan Grimm et al., (2002), yang menyatakan bahwa Desulfotomaculum merupakan kelompok bakteri yang menggunakan ion sulfat sebagai penghasil $\mathrm{H}_{2} \mathrm{~S}$ untuk kelangsungan hidup dari bakteri tersebut. Menurut Widyati (2017), Desulfotomaculum dapat dimanfaatkan dalam proses bioremediasi tanah bekas tambang batu bara yang dengan waktu inkubasi 20 hari dapat menunjukkan aktivitas penurunan konsentrasi sulfat sehingga tanah yang telah tercemar dapat kembali subur.
Pada uji biokimia isolat $\mathrm{SL}_{2}$ diperoleh hasil positif terhadap uji katalase dan uji fermentasi karbohidrat. Berdasarkan hasil tersebut dapat disimpulkan bahwa isolat bakteri $\mathrm{SL}_{2}$ diduga sebagai genus bakteri Brochothrix yang telah disesuaikan dengan buku Bergey's Manual of Determinative Bacteriology $9^{\text {th }}$ Edition.

Uji biokimia berikutnya yaitu pada isolat bakteri simbion spons Phyllospongia lamellose isolat $\mathrm{SL}_{3}$, yang memperlihatkan hasil positif terhadap uji katalase serta hasil negatif terhadap uji fermentasi karbohidrat dan uji motilitas. Berdasarkan hasil tersebut selanjutnya disesuaikan dengan buku Bergey's Manual of Determinative Bacteriology $9^{\text {th }}$ Edition yang kemudian ditarik kesimpulannya bahwa isolat $\mathrm{SL}_{3}$ diduga sebagai genus Sulfidobacillus. Hasil penelitian yang menduga bahawa isolat $\mathrm{SL}_{3}$ merupakan bakteri Sulfidobacillus didukung dengan hasil penelitian yang dilakukan oleh Rukmana dan Zulaika (2017) menunjukkan karakterisitik dari bakteri Sulfidobacillus berdasarkan buku Bergey's Manual of 
Determinative Bacteriology ialah sel bakteri berbentuk basil, termasuk dalam kelompok bakteri Gram positif, motilitas negatif dan katalase positif.

\section{Kesimpulan}

Isolat bakteri simbion spons Phyllospongia lamellose menunjukkan adanya aktivitas antibakteri terhadap bakteri uji yang termasuk dalam kategori sedang. Diameter rata-rata zona bening yang dihasilkan ketiga isolat terhadap bakteri Staphylococcus aureus yaitu: $\mathrm{SL}_{1}(8.67$ $\mathrm{mm}), \mathrm{SL}_{2}(9.33 \mathrm{~mm})$ dan $\mathrm{SL}_{3}(9.00 \mathrm{~mm})$. Sedangkan terhadap bakteri Esherichia coli yaitu: $\mathrm{SL}_{1}(9.67 \mathrm{~mm}), \mathrm{SL}_{2}(9.00 \mathrm{~mm})$ dan $\mathrm{SL}_{3}$ $(9.33 \mathrm{~mm})$. Identifikasi secara biokimia terhadap ketiga isolat masing-masing teridentifikasi sebagai Desulfotomaculum $\left(\mathrm{SL}_{1}\right)$, Brochothrix $\left(\mathrm{SL}_{2}\right)$ dan Sulfidobacillus $\left(\mathrm{SL}_{3}\right)$.

\section{DAFTAR PUSTAKA}

Achiruddin, I. 2005. Pemantauan Perubahan Garis Pantai di Pantai Timur Surabaya dengan Teknologi Penginderaan Jauh. Jurnal Geoid. 1(1): 81-86.

Adila, R., Nurmiati., Agustien, A. 2013. Uji Antimikroba Curcuma spp. Terhadap Pertumbuhan Candida albicans, Staphylococcus aureus dan Esherichia coli. Jurnal Biologi. 2(1): 1-7.

Borges, M. T dan Bresson, W. 2004. Delivery Methods for Introducing Endophitic Bacteria into Maize. Biocontrol. 49: 315-322.

Brooks, G. F., Butel. J. S., Morse S. A. 2008. Medical Microbiology. McGraw Hill, New York.

Departemen Teknologi Hasil Perairan, Departemen Ilmu dan Teknologi Pangan, Departemen Biologi. Karakterisasi Awal Inhibitor Protease dari Bakteri yang Berasosiasi dengan
Spons Asal Pulau Panggang Kepulauan Seribu. 2006. 13(2): 58-64.

Feliatra. 2004. Isolasi dan Identifikasi Bakteri Probiotik dari Ikan Kerapu Macan (Ephinephelus fuscogatus) dalam Upaya Efisiensi Pakan Ikan. Jurnal Natur Indonesia. 6(2): 75-80.

Grimm, K dan Langendijk, P. 2002. Invitro Colonization of Sulfat Reducing Bacteria (SRB) on Resorbable Membranes for Periodantal Regeneration. Journal Antimicrobial and Anti Imflammatory. 3:45.

Hafsari, A. R. dan Asterina, I. 2013. Isolasi dan Identifikasi Kapang Endofit dari Tanaman Obat Surian. Jurnal Istek. 7(2): 175-191.

Harrow, G. I. dan Feltham. 2003. Cowan and Steel's Manual for The Identification of Medical Bacteria $3^{\text {th }}$ Edition. Cambridge University Press, United Kingdom.

Hidayat, H. 2011. Karakterisasi Molekuler BAL Dengan Gen $16 S$ rRNA Penghasil Enzim Protease Yang Berpotensi Sebagai Probiotik Dari Fermentasi Markisa Kuning di Sumatera Barat. Universitas Andalas, Padang.

John, G. H., Noel, R. K., Peter, H. A. S., James, T. S., Stanley, T. W. 1994 Bergey's Manual of Determinative Bacteriology $9^{\text {th }}$ Edition. Baltimore The Williams \& Wilkins Company, United States.

Oki, W. D., Judianti, M. M., Fiqri, M. K., Ansyori-KM, G. T. 2014. Aktivitas Antibakteri Isolat Bakteri yang Berasosisasi dengan Spons Demospongiae dari Pantai Paciran Lamongan. Sains dan Matematika. 2(2): 2302-7290.

Oretz, J. H. 2005. Disk Diffusion Testing in Manual of Antimicrobial Susceptibility 
Testing. American Society for Microbiology, USA.

Rukmana, G dan Zulaika, E. 2017. Isolasi bakteri Karbonoklastik dari Pegunungan Kapur. Jurnal Sains dan Seni. 6(2): 2337-3520.

Tansil, A. Y. M., Edward, N., Jimmy, P., Robert, A. B. 2016. Uji Daya Hambat Ekstrak Etanol Daun Srikaya (Annona Squamosa) Terhadap Pertumbuhan Bakteri Esherichia coli dan Staphylococcus aureus. Jurnal eBiomedik. 4(2).

Valgas, C., Souza, S. M. D., Smania, E. F. A, and Artu, S. 2007. Screening Methods to Determine Antibacterial Activity of Natural Products. Brazilian Journal of Microbiology. 38: 369-380.

Widyati, E. 2017. Pemanfaatan Bakteri Sulfat untuk Bioremediasi Tanah Bekas Tambang Batubara. Jurnal Biodiversitas. 8(4): 283-286. 